\title{
PENATALAKSANAAN GIANT CELL TUMOR PADA DISTAL RADIUS: SEBUAH LAPORAN KASUS
}

\author{
Yuliaji Narendra Putra ${ }^{1}$, Rahadyan Magetsari ${ }^{2}$ \\ ${ }^{1}$ Program Studi Ilmu Bedah, Fakultas Kedokteran Universitas Gadjah Mada, RSUP Dr. Sardjito. Korespondensi: \\ yp_narendra@yahoo.com. \\ ${ }^{2}$ Divisi Orthopaedi dan Traumatologi, Fakultas Kedokteran Universitas Gadjah Mada, RSUP Dr. Sardjito.
}

\begin{abstract}
ABSTRAK
Latar belakang: giant cell tumor adalah suatu tumor jinak tulang yang meskipun jarang menyebabkan kematian, tetapi berpotensi untuk menjadi agresif dan mempunyai kemampuan untuk bermetastasis. Kasus: seorang perempuan berusia 20 tahun datang ke rumah sakit dengan keluhan terdapat benjolan di pergelangan tangan sebelah kiri yang telah berlangsung selama 6 bulan. Benjolan tersebut semakin lama dirasakan semakin membesar dan nyeri namun tidak mengganggu pergerakan dari pergelangan tangan. Pada pemeriksaan fisik ditemukan massa solid berukuran $5 \times 3 \times 2 \mathrm{~cm}$ dengan kesan terfiksir tulang tanpa tanda peradangan. Range of motion sendi pergelangan tangan masih dalam batas normal. Pada pemeriksaan radiologi ditemukan ekspansil, osteolitik ekstraosseus, serta lesi radiolusen tanpa batas sklerotik, dan reaksi periosteal pada akhir distal radius. Pasien ini didiagnosis dengan giant cell tumor radius distal kiri, kemudian dilakukan penanganan berupa eksisi tumor dan rekonstruksi dengan auto bone graft dari fibula. Evaluasi rutin selama 5 tahun menunjukkan hasil yang baik yang mana tidak tampak tanda-tanda rekurensi, tidak ada reaksi penolakan graft, dan range of motion sendi pergelangan tangan tetap dalam batas normal. Simpulan: tatalaksana giant cell tumor dengan eksisi dan rekonstruksi menggunakan auto bone graft menunjukkan hasil yang baik dan memuaskan.
\end{abstract}

Kata kunci: giant cell tumor, eksisi tumor, rekonstruksi, auto bone graft.

\section{TREATMENT OF GIANT CELL TUMOR ON DISTAL RADIUS: A CASE REPORT}

\author{
Yuliaji Narendra Putra ${ }^{1}$, Rahadyan Magetsari ${ }^{2}$ \\ ${ }^{1}$ General Surgery Training Programme, Faculty of Medicine Gadjah Mada University, Dr. Sardjito Hospital. \\ Correspondence: yp_narendra@yahoo.com. \\ ${ }^{2}$ Orthopaedi and Traumatology Division, Faculty of Medicine Gadjah Mada University, Dr. Sardjito Hospital.
}

\begin{abstract}
Background: giant cell tumor is a benign bone tumor that even though very rare to cause lethal complications, but it can become aggressive and has the ability to metastasize. Case: a 20 -years-old woman was admitted to the hospital with a mass on her left wrist that has been going on for 6 months and has enlarged slowly, but didn't interrupt the wrist movement. On physical examination, there was painful but uninfected solid mass sized $5 \times 3 \times 2 \mathrm{~cm}$ on the left wrist joint, fixed to the bone. Range of motion was still normal. On radiologic finding, there were expansile, extraosseous osteolytic, radiolucent lesion without sclerotic border, and periosteal reaction on the end distal radius. This patient was diagnosed with left distal radius giant cell tumor, the patient underwent tumor excision and auto bone graft reconstruction from fibula. Routine follow-up of 5 years, showed good results
\end{abstract}


where there were no signs of recurrent nor rejections from the body for the graft, and still within normal range of motion on the wrist joint. Conclusion: the treatment of giant cell tumor with excision and auto bone graft reconstruction seems to show good and satisfying results.

Keywords: giant cell tumor, tumor excision, reconstruction, auto bone graft.

\section{PENDAHULUAN}

Giant cell tumor (GCT) pada tulang merupakan tumor muskuloskeletal yang jarang terjadi. ${ }^{1,2}$ GCT pertama kali dilaporkan oleh Cooper pada abad 18, namun baru pada tahun 1940 mendefinisikan GCT secara tegas dari tumor lain. ${ }^{1}$ GCT mencakup 4-5\% dari insidensi tumor tulang primer dan $18,2 \%$ dari insidensi tumor tulang jinak. ${ }^{1,3}$ Sekitar 60\% GCT terjadi pada tulang panjang dan hampir semua terjadi pada ujung distal tulang, terutama di femur, humerus, dan radius. ${ }^{2,4}$ Pada radius distal merupakan area tersering ke-3 terjadinya GCT (10$15 \%$ kasus) setelah femur distal dan tibia proksimal. $^{5}$

GCT memiliki gambaran mikroskopis yang menyerupai tumor tulang lainnya, yang juga memiliki gambaran multinucleated osteoclast-like giant cell seperti chondroblastoma, chondromyxoid, fibroma, dan giant cell sarcoma. ${ }^{6}$ Penegakan diagnosis melalui pemeriksaan patologi anatomi tetap perlu dikonfirmasi dengan penemuan klinis. ${ }^{7}$ Banyak modalitas penatalaksanaan yang tersedia, tetapi $50 \%$ pasien ternyata tetap mengalami rekurensi lokal, bahkan pada beberapa kasus dapat terjadi metastasis ke paru.,4 Dalam laporan kasus ini, akan dipaparkan teknik eksisi luas dan rekonstruksi dengan auto bone graft dimana setelah dilakukan evaluasi followup rutin selama 5 tahun, ternyata tetap memberikan hasil yang baik dengan status bebas tumor.

\section{LAPORAN KASUS}

Seorang wanita berusia 20 tahun datang dengan keluhan terdapat benjolan di pergelangan tangan kiri yang sudah berlangsung selama 6 bulan. Sebelumnya, pada lokasi timbulnya benjolan itu pada mulanya terlihat bengkak, kemudian mengeras pada dua bulan terakhir dan perlahan mulai membesar disertai dengan adanya nyeri.

Pada pemeriksaan fisik ditemukan massa solid berukuran $5 \times 3 \times 2 \mathrm{~cm}$ di area pergelangan tangan kiri, dengan kesan terfiksir pada tulang. Tidak tampak adanya tanda-tanda peradangan, dan juga tidak ditemukan adanya nyeri tekan maupun gangguan neurovaskular. Range of motion pergelangan tangan kiri masih dalam batas normal. Pada pemeriksaan radiologi ditemukan gambaran ekspansil, osteolitik ekstraosseus, lesi radiolusen tanpa batas sklerotik dan reaksi periosteal pada ujung distal radius (Gambar 1).

Pada pemeriksaan darah lengkap tidak ditemukan adanya kelainan. Pasien ini didiagnosis dengan giant cell tumor radius distal sinistra dan dilakukan penanganan berupa eksisi tumor dengan rekonstruksi menggunakan auto bone graft dari fibula. Pada pelaksanaan operasi (Gambar 2), dilakukan Thompson approach dan ditemukan tumor yang tampak kebiruan dan teraba keras. Kemudian dilakukan eksisi dengan batas $2 \mathrm{~cm}$ dari massa tumor dan auto bone graft dari fibula, selanjutnya difiksasi dengan $1 / 3$ tubuler 7 holes dan cortical screw 2,7x12 mm 4 buah serta 
2,7x14 mm 2 buah. Persendian radioulnar lalu difiksasi dengan cortical screw $36 \times 15$ $\mathrm{mm}$, sedangkan radius dan metacarpal difiksasi dengan $\mathrm{K}$-wire $1,8 \mathrm{~mm}$.

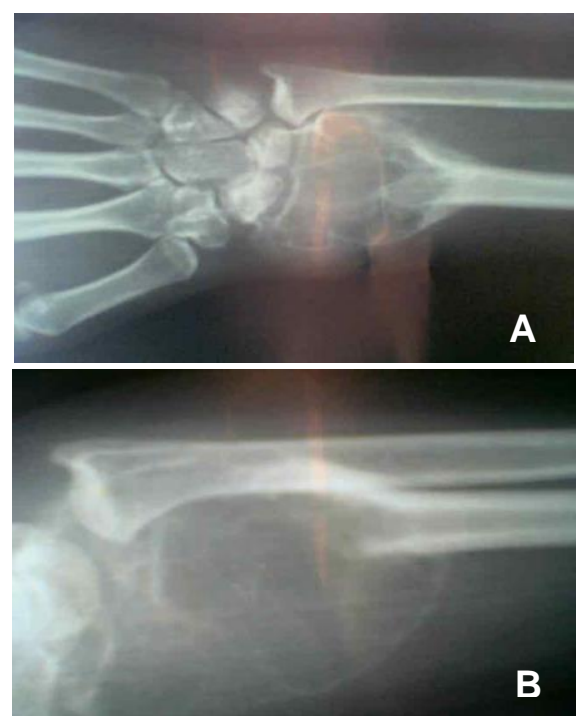

Gambar 1. Hasil pemeriksaan radiologi, tampak ekspansil, osteolitik ekstraosseus, lesi radiolusen tanpa batas sklerotik dan reaksi periosteal pada ujung distal radius baik pada posisi AP (A) maupun pada posisi lateral (B).

Total lama perawatan pasien adalah selama 5 hari. Hasil follow-up rutin pasien selama 5 tahun menunjukkan hal yang menggembirakan, dimana tidak ditemukan adanya tanda-tanda rekurensi ataupun tanda penolakan tubuh pasien terhadap fiksasi interna yang diimplan pada pergelangan tangan kiri pasien. Range of motion sendi pergelangan kiri pasien juga tetap dalam batas normal, dimana pasien dapat melakukan pekerjaannya serta aktivitasnya sehari-hari dengan baik.
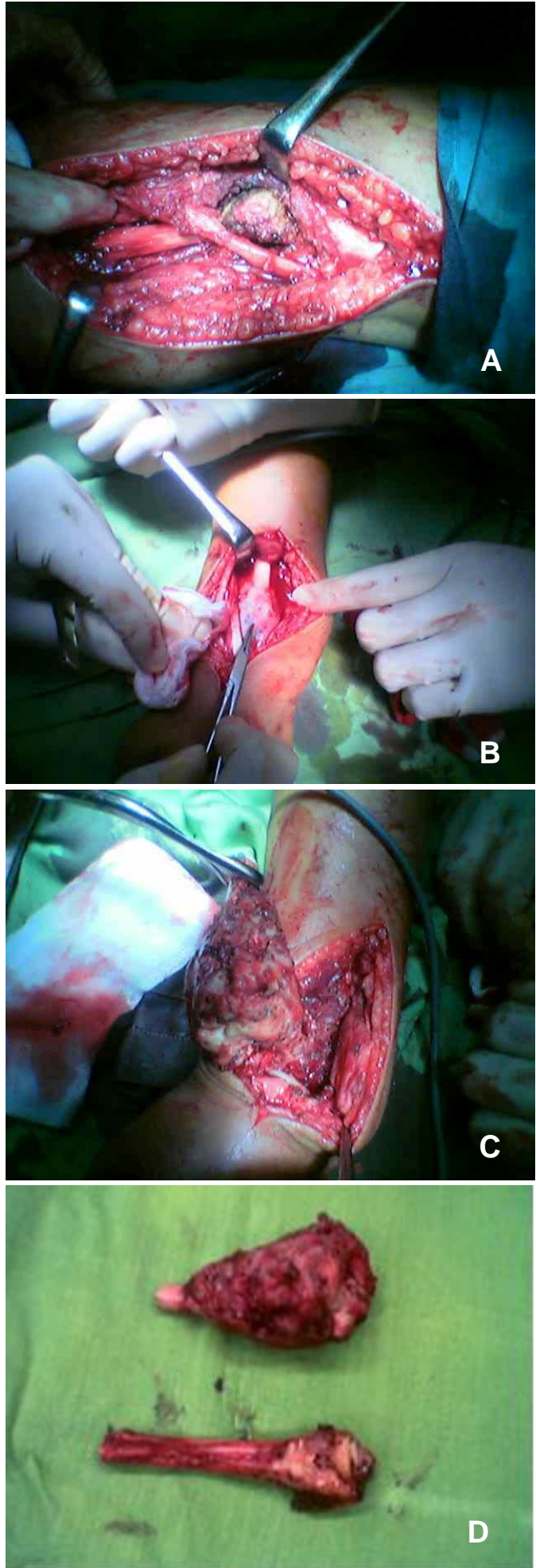

Gambar 2. Intraoperatif operasi ditemukan tumor dengan ukuran $5 \times 3 \times 2 \mathrm{~cm}$ berwarna kebiruan dan teraba keras (A) saat dilakukan Thomson approach (B). Penanganan selanjutnya adalah dilakukan eksisi tumor dan rekonstruksi dengan menggunakan auto bone graft $(\mathrm{C})$. Tampak hasil operasi yang memperlihatkan gambaran tumor yang sudah diangkat (D). 


\section{DISKUSI}

Pada kasus GCT ini, usia muda dan jenis kelamin pasien sesuai dengan insidensi pasien GCT yang memang lebih didominasi perempuan sebanyak 53\% dan puncak insidensi terjadi pada usia 20-30 tahun. ${ }^{2,3}$ Lokasi benjolan pada ujung distal tulang radius juga merupakan predileksi dari GCT. ${ }^{4}$ Keluhan nyeri pada benjolan di pergelangan tangan merupakan manifestasi klinis dari GCT. ${ }^{5}$ Tidak adanya riwayat penyakit metabolik dapat meyingkirkan diagnosis pembanding Brown Tumor pada penyakit hiperparatiroid. ${ }^{6}$

Lebih lanjut lagi, gambaran radiologi berupa gambaran expansil, osteolitik ekstraosseus, lesi radiolusen tanpa batas sklerotik dan reaksi periosteal pada ujung distal radius lebih mengarahkan diagnosis GCT. ${ }^{7}$ Penatalaksanaan GCT pada pasien ini menggunakan penatalaksanaan bedah, yaitu eksisi tumor dengan batas $2 \mathrm{~cm}$ dari massa tumor dan rekonstruksi dengan auto bone graft dari fibula. Metode ini dipilih karena merupakan metode yang ideal untuk penatalaksaanan GCT, dimana jarang menimbulkan rekurensi lokal dan dapat menjaga fungsi persendian terutama pada GCT dengan lesi ekstraosseus. ${ }^{7,8}$

Pada laporan kasus oleh Seradge, dilaporkan 2 orang pasien GCT pada distal radius yang mendapatkan terapi eksisi dan translokasi ulna, tapi tidak ditemukan rekurensi lokal serta range of motion juga masih dalam batas normal. ${ }^{9}$ Laporan kasus yang lain oleh Lackman et al. melaporkan 11 dari 12 pasien GCT pada distal radius yang mendapatkan terapi eksisi dan auto bone graft dari fibula ternyata juga tidak mengalami rekurensi lokal dan menunjukkan fungsi pergerakan pada lengan bawah serta pergelangan tangan pasien masih baik, dimana hanya 1 pasien saja yang menunjukkan nonunion antara graft dengan radius. $^{10}$ Murray et al. melaporkan dari 18 pasien GCT pada ujung distal radius yang dieksisi dan direkonstruksi dengan autograft fibula, terdapat 5 pasien yang ditemukan adanya rekurensi lokal, 3 pasien ditemukan adanya nonunion di radius dan fibula, sedangkan 10 pasien lainnya tidak ditemukan rekurensi lokal dan terjadi union. ${ }^{11} \mathrm{Hal}$ ini menegaskan hasil temuan pasien kami, dimana pada pasien ini tidak ditemukan adanya rekurensi lokal dalam rentang waktu follow-up rutin selama 5 tahun.

\section{SIMPULAN}

Penatalaksanaan GCT radius distal dengan metode eksisi dan rekonstruksi menggunakan auto bone graft menunjukkan hasil yang baik dan memuaskan, baik untuk jangka pendek maupun jangka panjang.

\section{DAFTAR PUSTAKA}

1. Peh WCG. Giant Cell Tumor Imaging. (serial online) 2015 Dec [cited 2018 September 5]. Available from: https://emedicine.medscape.com/article /389833-overview.

2. Brockman BS, Quinn RH. Giant Cell Tumor of Bone. OrthoInfo AAOS (serial online) 2016 Oct [cited 2018 September 6]. Available from: https://orthoinfo.aaos.org/en/diseases-conditions/giant-cell-tumor-of-bone/.

3. Kelly D, Mc Erlean S, Byrne D, et al. A case of thoracic giant cell tumor of bone and discussion of radiological features and current management practices. Radiol Case Rep. 2016;11:222-6.

4. Wheeless CR. Giant-cell tumor of bone. Wheeless' Textbook of Orthopaedics (serial online) 2017 [cited 2018 September 6]. Available 
from:

http://www.wheelessonline.com/ortho/ giant_cell_tumor_of_bone.

5. Wysocki RW, Soni E, Virkus WW, et al. Is intralesional treatment of giant cell tumor of the distal radius comparable to resection with respect to local control and functional outcome?. Clin Orthop Relat Res. 2014;473:70615.

6. Pardiwala DN, Vyas S, Puri A, et al. Pictorial essay: Giant cell tumor of bone. Indian $J$ Radiol Imaging. 2001;11:119-26.

7. de Groot H. Giant Cell Tumor. (serial online) 2006 Nov [cited 2009 Nov 20]. Available from: http://bonetumor.org/tumors/pages/pag e106.html.

8. Harness NG, Mankin HJ. Giant cell tumor of the distal forearm. $J$ Hand Surg Am. 2004;2:188-93.

9. Seradge H. Distal ulnar translocation in the treatment of giant cell tumor of the distal end of the radius. J Bone Joint Surg Am. 1982;64:67-73.

10. Lackman RD, McDonald DJ, Beckenbaugh RD, et al. Fibular reconstruction for giant cell tumor of the distal radius. Clin Orthop Relat Res. 1987;218:232-8.

11. Murray JA, Schlafly BJ. Giant cell tumor in the distal end of the radius: treatment by resection and fibular autograft interpositional arthrodesis. $J$ Bone Joint Surg Am. 1986;68:687-94. 